\title{
インターネットの活用による 都市・農村交流の可能性と課題
}

A Study on Urban and Rural Interaction by Internet

\section{後 藤一寿*・新沼 勝 利** \\ Kazuhisa Goto and Katsutoshi NIINUMA}

\section{I はじめに}

平成11年に制定された食料・農業・農村基本法 の第36条において, 都市と農村の交流の重要性が 明記され，今後の政策の柱の一つとして位置付け られている。特に，農業・農村の持つ多様性とそ の存在価値を評価し，都市住民と農村住民の相互 のメリットを享受しながら，継続的に交流が盛ん となることを重要視した本条は，新たな農村計画 展開の基碟を与えるものである。また，都市と農 村の交流を考える上で，都市・農村住民双方の情 報発信は重要である。宮口も，「ある地域とある 地域の間に物や人が両方から流れることによって， 両地域の生産・消費のキャパシティは高まり，当 然ながら経済は活発化する。最近ではこれに加え て情報の流れも大きな意味を持つようになってき た。」2)と，指摘し，情報の受発信による交流を視 野に入れている。特に近年のI T技術の普及には 目を見張るものがあり，都市・農村交流において インターネット（以下 I Nと表記する。）による 情報発信の重要性と可能性を否定することはでき ない注1)。特に I N は従来，単なる情報発信の媒 体の一つであったが, 近年ではマーケティングッー ル,コミュニケーションツールとしての機能や活 用に注目が集まっている注2)。農業の分野でも， 産直や電子商取引など流通の分野での活用が盛ん になってきた。しかしながら都市・農村交流といっ た分野での活用は，さほど多くはない注3)。
ところで，情報発信をするからには，その情報 の受け手が存在する。都市・農村交流を考えたと きにその情報の受信者は都市住民である。すなわ ち，余暇を過ごす町や移住先を探している都市住 民は，農村住民の顧客として考えてよいだろう。 現在, 一方的な情報発信が多い中, 都市住民の求 めている情報のニーズを把握する必要性は否定で きない。たとえば，P.Kotlerは著書「MARKETING PLACES」の中で, まちの買い手の情報源 を次の 4 つにまとめている。すなわち，(1)個人的 な情報源（家族, 友人, 隣人, 知人), (2)商業的 な情報源（宣伝，セールスマン，旅行業者)，(3) 公的な情報源（マスメディア，場所を順位づける 機関，専門家)，(4)経験的な情報源（実際にその 場所を訲れる) である。通常，買い手(ここでは 都市住民を意味する）はその情報の多くを商業的 な情報源から受け取る。一方，信頼できる情報源 は，個人的な情報源から受け取るとされている。 商業的な情報は，最初の情報を与える役目を果た し，個人的な情報が判断を正当化する役目を果た す。経験的な情報源は実際にその場所を訪れてみ て, 他の場所と比べてみる事で, 評価する役割を 果たす，とされている5)。

そこで本稿では, 今後 I Nの活用による都市・ 農村交流は可能かという疑問と, それらを実践し 成功させるための条件や課題は何であるかという 問題意識に立ち, 先に挙げたコトラーの考えにも とづき，都市・農村交流に関連する I N 上の発信

*東京農業大学大学院 Tokyo University of Agriculture, Graduate School of Agriculture

**東京農桑大学国际食料情報学部 Tokyo University of Agriculture, Faculty of International Agriculture and Food Studies

Key Words：1)インターネット，2)WE Bサイト，3）オンライン・コミュニティ，4) 都市・農村交流 
情報を分析し，I Nにより積極的に都市・農村交 流を実践している事例を取り上げ，IＮの活用に よる都市・農村交流の可能性と課題について考察 する。

\section{II 都市・農村交流の関連サイトの分析}

\section{1 調查の目的と方法}

ここではI Nで「都市と農村の交流」に関連し た情報発信を行っているWE Bサイトを対象と し，そこで発信されている情報の内容および発信 者の属性を分類し，その傾向と特徴を明らかにす ることを目的とする。まず，特に農村部からの情 報発信に着目して，登録式の検索エンジンである Yahoo！Japan注4)を用いて「都市と農村の交流」 に関連すると思われるキーワード（ふるさと，農 村, 農家, 農産物, 生産者, 産直, 直売所, 農業 体験, 観光農園, グリーンッーリズム) を入力し サイトを検索した。なお，ここで農村部からの情 報発信に着目した理由は，都市住民を農村交流， 農村空間, サービスの買い手あるいは情報の主た
る受信者と考えるからである。調査を行った平成 13 年 8 月現在, ヒットした登録サイトは 922 サイ トであったが, 複数のキーワードで重袮登録して いるサイトおよび紹介文などから判断し，467サ イトに絞りこれらをすべて閲筧するという方法を とった。ただし，467サイトのうち既に存在しな いサイトや都市・農村交流に直接関係のないと思 われるサイトを排除した319サイトについて集計 を行った。集計の方法は，それぞれのサイトが発 信している情報やコンテンッをすべて記録する方 法をとった。さらに，それらの情報やコンテンッ を類似した項目で分類した。また，発信者の区分 を農家, 農業法人, J A関連, 行政, 団体, 企業, 個人としている。なおここでいう団体には，む らづくり組織や商工会, 観光協会などを含んでい る。また，個人とは，先にあげたキーワードで登 録している一般市民のサイトであり，農家のそれ とは区別している。

\section{2 調査の結果と考察}

表 1 は都市・農村交流関連サイトの発信情報を
表 1YYahoo！に登録されている都市・農村交流関連サイトの発信情報

\begin{tabular}{|c|c|c|c|c|c|c|c|c|c|c|c|c|c|c|c|c|}
\hline \multirow[t]{2}{*}{ 発信情郝 } & \multicolumn{2}{|c|}{$\begin{array}{c}\text { 全体 } \\
(\mathrm{n}=319)\end{array}$} & \multicolumn{2}{|c|}{$\begin{array}{c}\text { 党家 } \\
(\mathrm{n}=57)\end{array}$} & \multicolumn{2}{|c|}{$\begin{array}{l}\text { 䜊法人 } \\
(n=14)\end{array}$} & \multicolumn{2}{|c|}{$\begin{array}{l}\mathrm{J} A \text { 附連 } \\
(\mathrm{n}=37)\end{array}$} & \multicolumn{2}{|c|}{$\begin{array}{c}\text { 行政 } \\
(\mathrm{n}=\mathbf{5 0})\end{array}$} & \multicolumn{2}{|c|}{$\begin{array}{c}\text { 団体 } \\
(n=76)\end{array}$} & \multicolumn{2}{|c|}{$\begin{array}{c}\text { 企率 } \\
(n=35)\end{array}$} & \multicolumn{2}{|c|}{$\begin{array}{c}\text { 佃人 } \\
(\mathrm{n}=50)\end{array}$} \\
\hline & 順位 & $\%$ & 順位 & $\%$ & 順位 & $\%$ & 順位 & $\%$ & 順位 & $\%$ & 碩位 & $\%$ & 㖽位 & $\%$ & 順位 & $\%$ \\
\hline メール受付 & A & 88.7 & 1 & 94.7 & 5 & 92.9 & a & 91.9 & a & 90.0 & Ha & 81.6 & 6 & 82.9 & (1) & 92.0 \\
\hline リンク集 & (2) & 64.9 & 5 & 59.6 & 4 & 57.1 & 3 & 81.1 & 3 & 70.0 & (2) & 67.1 & 3 & 45.7 & 3 & 66.0 \\
\hline 特産品·醉品埥般 & 3 & 60.2 & (2) & 89.5 & 5 & 92.9 & 50 & 91.9 & 8 & 54.0 & $\Delta$ & 50.0 & (2) & 51.4 & 10 & 22.0 \\
\hline 地域情辄 & 4 & 50.5 & 12 & 15.8 & - & 0.0 & 6 & 43.2 & (2) & 84.0 & 3 & 60.5 & 6 & 40.0 & (2) & 68.0 \\
\hline プロフィール & (5) & 49.5 & 4 & 63.2 & 4 & 57.1 & 4 & 64.9 & 7 & 56.0 & 8 & 40.8 & 9 & 22.9 & 6 & 46.0 \\
\hline 交通案内 & 6 & 39.8 & 10 & 29.8 & 6 & 50.0 & 8 & 24.3 & 6 & 58.0 & 6 & 48.7 & 4 & 42.9 & 11 & 26.0 \\
\hline イベ & 7 & 37.0 & 17 & 8.8 & 8 & 28.6 & 7 & 37.8 & 5 & 64.0 & 7 & 46.1 & 7 & 31.4 & 8 & 34.0 \\
\hline 産直情辄 & 8 & 33.9 & 3 & 66.7 & 3 & 78.6 & (5) & 51.4 & 14 & 6.0 & 11 & 23.7 & 40 & 42.9 & 14 & 8.0 \\
\hline 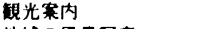 & 9 & 33.5 & $\overline{18}$ & 7.0 & - & 0.0 & 14 & 10.8 & 3 & 70.0 & 4 & 50.0 & 7 & 31.4 & 9 & 30.0 \\
\hline 地域の風貫写真 & 10 & 31.3 & 14 & 14.0 & - & 0.0 & 10 & 18.9 & $\overline{9}$ & 42.0 & 9 & 34.2 & 11 & 20.0 & 4 & 62.0 \\
\hline 電子揭示板（B B S） & 11 & 28.8 & 7 & 35.1 & 15 & 7.1 & 10 & 18. 9 & 11 & 18.0 & 10 & 30.3 & 9 & 22.9 & (5) & 48.0 \\
\hline 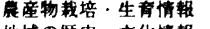 & 12 & 16.0 & 6 & 52.6 & 6 & 50.0 & 17 & 2.7 & 18 & 2.0 & 17 & 9.2 & 16 & 5.7 & 15 & 6.0 \\
\hline 地域の麼史・文化情報 & 13 & 15.7 & - & 0.0 & 14 & 7.1 & - & 0.0 & 10 & 32.0 & 12 & 15.8 & 18 & 2.9 & 7 & 40.0 \\
\hline 日即·通傗 & 14 & 12.5 & 7 & 35.1 & 10 & 21.4 & 17 & 2.7 & 14 & 6.0 & 16 & 10.5 & - & 0.0 & 12 & 10.0 \\
\hline 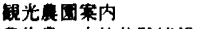 & 15 & 11.9 & 11 & 28.1 & 8 & 28.6 & 17 & 2.7 & 16 & 4. 0 & 15 & 11.8 & 14 & 8.6 & 15 & 6.0 \\
\hline 晨作萐·自然体験情䡑 & 16 & 11.3 & 15 & 12.3 & 11 & 14.3 & 16 & 5.4 & 13 & 8.0 & 12 & 15.8 & 11 & 20.0 & 19 & 4.0 \\
\hline 農作策紹介 & 17 & 10.0 & 7 & 35.1 & 11 & 14.3 & 13 & 13.5 & 18 & 2.0 & 22 & 2.6 & 18 & 2.9 & 21 & 2.0 \\
\hline 特产品の枓理レシビ & 18. & 9.7 & 12 & 15.8 & 11 & 14.3 & 9 & 21.6 & 15 & 4.0 & 18 & 7.9 & 14 & 8.6 & 21 & 2.0 \\
\hline 宿泊寨内 & 19 & 8. 5 & 20 & 1.8 & - & 0.0 & - & 0.0 & 12 & 12.0 & 12 & 15.8 & 13 & 14.3 & 15 & 6.0 \\
\hline Q\&A & 20 & 5.3 & 16 & 10.5 & 15 & 7.1 & 14 & 10.8 & 15 & 4.0 & 21 & 3.9 & 18 & 2.9 & - & 0.0 \\
\hline 求人倘辄 & 21 & 3.4 & 20 & 1.8 & 11 & 14.3 & 12 & 16.2 & - & 0.0 & - & 0.0 & 16 & 5.7 & - & 0.0 \\
\hline Englishベージ & 22 & 2.8 & 20 & 1.8 & 15 & 7.1 & - & 0.0 & 18 & 2.0 & 19 & 6.6 & - & 0.0 & 21 & 2.0 \\
\hline ベージ内検索ジ & 23 & 2.8 & - & 0.0 & - & 0.0 & 17 & 2.7 & 18 & 2.0 & 20 & 5.3 & 18 & 2.9 & 19 & 4.0 \\
\hline メーリンダリスト(ML) & 24 & 2.5 & 19 & 3.5 & 15 & 7.1 & - & 0.0 & - & 0.0 & 24 & 1.3 & 18 & 2.9 & 15 & 6.0 \\
\hline ント & 25 & 2.5 & - & 0.0 & - & 0.0 & - & 0.0 & - & 0.0 & 22 & 2.6 & 18 & 2.9 & 12 & 10.0 \\
\hline 災褰情䢁 & 26 & 0.6 & - & 0.0 & - & 0.0 & - & 0.0 & 18 & 2.0 & - & 0.0 & - & 0.0 & 24 & 2.0 \\
\hline メールマガジン & 27 & 0.3 & 20 & 1.8 & - & 0.0 & - & 0.0 & - & 0.0 & - & 0.0 & - & 0.0 & - & 0.0 \\
\hline & 度数 & $\%$ & 度数 & $\%$ & |度数 & $\%$ & 度数 & $\%$ & 度数 & $\%$ & 度数 & $\%$ & 度数 & $\%$ & 度数 & $\%$ \\
\hline 独自ドメイン名の取得 & 80 & 25.1 & 5 & 8.8 & 2 & 14.3 & 29 & 78.4 & 16 & 32 & 16 & 21.1 & 10 & 28.6 & 2 & 4.0 \\
\hline
\end{tabular}

単純集計した結果 であり，全体にお いて発信情報の割 合が高い順に整理 したものである。 発信者区分で最も 多かったサイトは 団体の23.8\%であ り，次いで農家の $17.8 \%$, 個人, 行 政の $15.6 \%$ となっ ている。発信情報 の合計値を見てみ ると， 5 割以上の サイトで発信され ている情報は「メー ルの受付」(88.7 \%),「リンク集」

(64.9\%)，「特産 品·商品情報」 $(60.2$ $\%$ ）「地域情報」 (50.5\%) などで 
あり，各発信者が共通に発信している基本情報と いえる。特徵的な点では, 農家, 宸業法人, J A 関連については，5割以上が「特産品・商品」 「産直情報」を発信している。また，農家と農業 法人については「譨作物の栽培や生育情報」など を公開し，商品の詳細なP R を行っている。また， 行政，団体，個人の 6 割以上が「地域情報」を発 信しており，さらに，行政や団体ならびに個人の ホームページでは「钼光情報」や「地域の風景写 真」を揭载しているページが多い点も特徵として あげられる。

これらから, 都市・農村交流の関連するサイト は農産物の産直やP R を中心に行う宸家・農業法 人，J Aなどにより主に開設されている営利目的 のサイトと，地域の P R や意見交換などを中心に 行う，行政や団体，個人により開設されている非 営利目的のサイトに分類でき，それぞれの立場か ら, 都市・農村交流, あるいは農業・農村に関す る情報発信を行っている样子がうかがえる。以上 のような考察に基づき, 公共性の視点から，非営 利目的のサイトよりむらづくり組織での活用事例 と, ビジネスの視点から, 営利目的のサイトより 尨家に上る活用事例を取り上げ, 目的の違う両者 がI Nの活用によりどのような形で都市・農村交 流を実践しているのか更に考察する。

\section{III インターネットによる都市・農村交流の 事例}

1 むらつくり組織による情報発信と活用状況

和歌山県田辺市で活動している秋津野塾は, 平 成 6 年 9 月に, 町内会や公民館, 農協青年部や婦 人部，さらには商工会青年部など 20 団体により組 織され発足したむらつくり組織である。この秋津 野塾の活動地域である上秋津地区は，11集落から なる旧村で, 田辺市のほほ中央部に位置する農村 地帯である。平成 8 年度には農林水産祭むらづく り部門において天皇杯を受賞しており，その実縝 が高く評価されている。近年, 交通の利便性の向 上と, 市街地の拡大などにより人口が增加し，混 住化が問題となっている。しかしながら，先の秋 津野塾を中心に, 年間50回を越える代表者会議や, 数々のイベントを企画運営しながら,これからの
むらづくりを地域住民が主体となって考え行動し ている特徽的な事例である。この秋津野熱には地 域内の青年を中心とした秋津野情報技術利用推進 轨があり，地域のイベント，史跡や風累などを VTRに収録したり，ホームページを作成したり しながら，地域の情贯や地域内の各種情報を皘極 的に発信している。

秋津野熱のWE Bサイトは，1997年 9 月に開設 して以来, 随時更新を重ねている注5)。主な発信 情報は，地域内でのイベント情報や地域内メーリ ンタリスト、リンク集や防災情報といった地元住 民に对する情報発信と，地域の歴史や文化，むら つくりの内容紹介といった地域外への情報発信に 分けられる。登録者全貝に同じメールが発信され るメーリングリストでは, 地域内の情報や話題, 営農情報などを中心に活用されている。また, 地 域外への情報発信では，地域の歴史や文化ならび に地域行事などを多くの写真と共に紹介している ので，秋津野にいなくても地域の情贯を容易に想 像でき，ふるさとを身近に感じることができる。

現在, サイトの企画運営は秋津野情報技術利用 推進班で行っているが, 担当者の本業は, 果樹専 業農家であり、このサイトの制作・運営は同氏の ボランティア活動によって行われている。サイト の運営コストも，サーバー管理費の年18,000円と 通信费のみである。今後の課題や目標は, 地域外 への情報発信もさることながら，もっと地域内で の情報発信及び活用に力を入れたいとのことであっ た。具体的にはトップページに地域内情報の揭示 板を設置し，毎日情報更新を行い，地域の回筧板 の機能をこのホームページに持たせたいとのこと である。そのためには迅速な情報更新ができる人 材の育成と, 正確な情報の集積の仕組みづくりが 課題であり，現在検討中とのことであった。また， 地域外の人への情報発信としては, 定期的なメ一 ルマガジンの発行などにより，常にこのサイトで 上秋津地域に触れることができる仕組みを考えた いとのことである。

ここで見てきたように，むらづくり活動をして いる秋津野熟のような組織の情報発信にはいくつ かの特徽を見出す事ができる。すなわち，I Nを 活用する事による新たな地域コミュニティの形成 
と，都市・農村交流の推進，あるいは農村文化の 継承を目指している点である。地域内外の多くの 人たちに地域の資源，歴史，イベントなどを知っ てもらい，興味をもってもらい，その結果として 地域振興が実現できれば，情報発信の効果は大き いであろう。またここれら実践するためにはい くつかの課題も明らかとなった。地域内での世代 間による情報リテラシー（情報機器を使いこなす 能力）・技術格差の是正, 誰もが I T 技術を駆使 できる教育などはもちろんの事, 地域住民同士の コミュニティッールとして，地域内情報を一極集 中させ，全世带に公平に発信するシステム作りが 課題である。それにともない，今後ますますアク 七スの状況が多くなれば, 地域密着型ならびに住 民参加型の情報発信基地の役割を果たしてくると いえよう。

\section{2 家による情報発信と活用状況}

福岡県の東南端に位置し, 面積の䄪 9 割が山林 という, 山あいの静かな村, 矢部村に位㯰する栗 原製茶工場テ・ファームはヤブキタ茶を中心に， 茶2.2haを栽培し, 自社工場で加工・販売を行っ ている農家である。まだI Nがあまり普及してい ない 95 年 7 月に自社のホームページを開設して以 来, 産直販売 (電直販売) p消費者との交流会で あるOF F 会の開催など，積極的にINを活用し て都市・農村交流を実践している。

95年 7 月に開設された栗原製茶工場テ・ファー ムのWE Bサイトは随時更新を重ね, ホームペー ジ公開以来, 累積約 1 万件, 1 日平均 7 名ほどの アクセスがある注6)。トップページでは，「普通の お茶は作りません」というキャッチコピーがまず 目に付き，現在のコンテンツは，産直情報のほか， お茶の栽培や加工方法を写真を交えて説明するぺー ジや，おいしい挍茶の入れ方，拈茶の有効成分な どを紹介したページ，消費者との交流を目的とし たB BS（電子掲示板）やOF F 会案内など多彩 なコンテンツが並んでいる。サイトの開設・運営 にかかるコストは, 制作費が約100,000円，サー バー管理費が年積 24,000 円，通信費が月積 10,000 円程度であり，通常かかる宣伝広告費及び営業経 費の大幅な削減になっている。

このサイト開設の目的は, 時間と空間の隔たり
がない I N上に店舗，すなわちヴアーチャルショッ プを持つことであった。その背景には山間部に位 置する同村において，通常のように店舖を構えて もその経済的効果は望めないという地理的制約が 大きい。もともと，ロコミによる直接販売ですべ てのお茶を販売していた栗原製茶工場にとって， I Nの活用は，最小限のコストで効果的に新規顧 客を開拓する絶好の手段であった。WE Bサイト 開設以来，このサイトにより年間平均 50 名ほどの 新規顅客があり，これまでに総計 300 名程の新規 顧客を開拓した。この新規顧客からの注文は売上 にして月平均 3 万円程度であり，一般に農産物の 電子商取引の成功例が少ない中で，まずまずの成 績と言える注7)。ここで獲得した顧客は必ずリピー ターとなり，今後も継続的に注文を入れてくるそ うである。そのような仕組みにより売上も順調に 伸びており，I N活用の経済的効果がうかがえる。

さらに特筆すべきは，このホームページがきっ かけとなって，ネット上で知り合った人々との交 流が始まっている点である。ホームページを開設 して以来，毎年 7 月に工場のある矢部村にて 2 泊 3 日の「釜緑茶・紅茶・ウーロン茶を作る会」と いうOFF会を実施している。OFF会とはネッ ト上でつながっている状態をONラインというの に対し，それから切り離されたOFFライン，す なわちネットではなく現実に会って交流する会の 事を棇称してそういう。このOF F 会の目的は消 費者との交流もさることながら，消費者に対しお 茶の作り方や加工までの行程を説明し，実際にす べての工程を体験してもらうことである。初年度 の参加者は 5 名であったが, 平成13年の参加者は 約30名であった。ほとんどが都市住民であり，お 茶の加工体験を通じて農業・農村を身近に感じて もらう草の根的な交流活動となっている。受け入 れ側として地域住民の参加も多く，地域を巻き込 んでのOF F 会は年々盛況となってきている。

このような個別農家によるI Nの活用は，従来 の系統農協出荷といった流通形態に乗らず, 自ら 販路を拡大させていく発想の元に運営されている 事が多い。消费者に顔の見える形で商品をP R L, I N上での交流を通じて，ビジネスを拡大させて いる点が特徵である。特に，消費者があまり目に 
できなかった生産現場や農作業などの写真を公開 し、より詳細な商品情報として提供する仕組みは, より良いものを求める消費者にとって，商品選択 の重要な情報として受け入れられる。また，I N 上で, 揭示板や電子メールにより生産者と直接交 流できる事が、ホームページ活用の最大の効果で ある。

このように生産者と消費者の間で「お茶」を通 じて形成されたオンライン・コミュニティは，コ トラーに例えるならば，消費者にとって「個人的 な情報源」としての機能をもっているといえ, こ こで筑かれた信頼関係が後の交流へとつながるの である。言い換えるならば,このようなサイトは, 不特定多数の人々が目にするI Nの世界でいかに このサイトや農場のファンを形成するかが大きな 課題である。そのためにも運営者の発想や企画力, さらにはきめ細やかなアフターケアが成功の大き なカギとなっている。

\section{IV 総括}

都市と農村の交流を念頭におき，I Nを活用し た情報発信の全体的な傾向と，それを実践してい る2つの事例を考察してきた。これらにより， I Nを活用した情報発信による都市・農村交流の 可能性と課題について整理する。

結論から言うと, I Nの活用による都市・農村 交流の可能性は大きいといえる。その根拠は, (1) I Nは一般的に，双方向での情報交換が最大の特 徵であり，IN上にオンライン・コミュニティを 形成でき，(2)農産物や的るさとに関する画像や動 画といったビシュアルな情報を多く発信できるた め, 現実に, 農村と都市を結ぶコミュニティの形 成が見られる。(3)安価なコストで新鮮な情報を広 く発信でき，小規模な農家やむらづくり組織など においてもそのメリットを享受できる。現に，広 告宣伝の費用として考えた場合, 公共性の高いむ らづくり組織などの貴重な活動費用の節約にもなっ ている。(4)I Nやオンライン上でのコミュニティ を活用することにより，都市住民のニースもかな り的確に把握できる。たとえば, 農産物の注文や 商品・サービスに対する反響やクレームなども貴 重な意見として収集できる。
これらの機能や特徽を活用しながら都市住民の 農山村への興味・関心を高め, I N上でのオンラ インの交流のみならず, オフラインの実際の交流 が盛んとなることが，I Nの活用による都市・農 村交流の大きな可能性といえよう。現に，事例で 取り上げた栗原製茶工場テ・ファームのWE Bサ イトのように，農山村からの積極的な情報発信が 交流の契機となって, オンラインからオフライン での交流へと発展している事実もあり, 今後の I N 活用の大きな可能性として強調しておく。ま た，先の 2 つの事例に共通して見られたオンライ ン・コミュニティー注8)の形成は従来のメディア では不可能であった点でもあり，I Nを活用する ことによる都市・農村交流成功の大きなカギとい える。このオンライン・コミュニティをWord Hansonは, オンラインの社交場と定義し「コミュ ニケーションが相互に行われ，ユーザーには情報 を消費するだけでなく，供給する責任もある。繰 り返される相互作用 (Interaction)によってコミュ ニティの社会性が高まり，信頼と継続性が生まれ る。」てと指摘しており，都市住民と農村住民のオ ンライン上での相互の交流の重要性を裹付けてい る。

今後の課題としては，(1)更なる情報技術の進歩 と普及，(2)若い世代から高齢者まで世代間の情報 技術格差の是正, (3)都市と農村といった地域間の 情報技術格差の是正, (4)誰もが I Nを活用できる ような教育やシステム作り，(5)都市住民の農山村 の発信する情報ニーズの把握, ならびに(6) I Nを 活用した情報発信の効果の測定などがあげられる。 特に, 都市・農村交流において I Nを活用する場 合は，常に最新の情報を提供することはもちろん の事, 地域や農村のファンをつくり, 継続的に交 流が続く仕掛けを作る事も重要である。

農業・農村の情報化や I Nの活用が盛んに言わ れて久しいが, もはや地方からの情報発信は，た だ情報を流しておけば良い時代ではなくなった。 これからは，情報の共有，さらにはＩ N上でのオ ンライン地域コミュニティの形成といった「活用」 の時代である。情報提供による都市・農村交流か ら, 情報共有, 地域コミュニティ形成といった都 市・農村共生に向けて, 魅力的な企画の立案, コ 
ンテンツの充実, ならびに I N 活用の具体的な経 済効果を明らかにする事が残された課題であろ う。

\section{補注}

注1）先に行われている摆查研究においてもこれらの 点を指摘している。参考文献 9 ) 参照。

注 2 ) 参考文献 6 )に詳しい。

注3）大石は参考文献 4) のなかで，都市農村関係と 言うマクロ的な梘点から見て興味深い事例はさは ど多くない。と指摘しつつ, 新规就農支援，非営 利組織による交流支援，直売所などでの事例を踏 まえて，その可能性について指摘している。

注 4 ) Yahoo! JapanURL : http://www. yahoo. co.jp

注 5 ) 秋津野熟URL : http://akizuno. net

注6）栗原製茶工場URL：http://www. mutugoro. or. $\mathrm{jp} /$ - kurihara

注 7 ）門間は参考文献 3）の中で, ネット直販のデメ リットをあげている。すなわち(1)販売量の子測が できない。(2)ホームページの作成・更新の労力と 人材不足，(3)投资に見合う収益の実現への不安な どである。また，一般的な電子用取引の動向は参 考文献 1)および8)に詳しい。

注 8 ）オンライン・コミュニティーは次の 4 つの重要 な特性を結び付けている。すなわち，(1)インター ネットをコミュニケーションッールとする，(2)コ ミュニティーの会員のための資格と规制，(3)ン パーの協同によるマテリアルづくり，(4)メンバー による反復利用である。参考文献 7 ）参照。

\section{引用文献・参考文献}

1）インターネットビジネス研究会著 (2001)：イン ターネットビジス白書2001, SOFT BANK.

2 ) 宮口侗廸 (1999)：相互刺激による洒値の創造, 農村計画学会誌Vol. 17 , No. 4, pp. 312-318.

3）門間敏幸・後藤一寿（印刷中）：農産物・食料品 の電子商取引の可能性 ·課題と展開方向, 農産物 に関する電子商取引の動向に関する調查，長期金 融, 財団法人農林水産長期金融協会.

4 ）大石和男 (2001) : 農的コンテンッとITの結合 による農村社会の变容，農業と経済第 67 巻，第 4 号, 富民協会, pp. 28-36.

5 ) P. Kotler D. Haider I. Rein (1993) : MARKETING PLACES (P.コトラー, D.H.ハイター, I.レイン著 井関利明監訳 (1996)：地域のマー ケティンク，東京経済新報社，pp. 52 .

6 ) Raymond Frost · Judy Strauss (1999) : Principal of Online Marketing, 1st edition Prentice-Hall, Inc（レイモンドフロスト、ジュディ・シュトラ ス (2000)：インターネット・マーケティング概 論, ピアソンエデュケーション).

7) Ward Hanson (2000) : Principal of Internet Marketing（ワード・ハンセン著 上原征彦監訳 長谷川真実訳 (2001)：オンラインコミュニティー, インターネットマーケティングの原理と戦略, 日 本経済新䦥社，pp. 374-420.)

8 ）財団法人日本情報処理開発協会（2001）:情報化 白書2001, コンピュータ・エージ社.

9 ) 財団法人 21 世紀村つくくり熟 (1999)：都市農村交 流等におけるインターネットの役割, 農業・農村 におけるインターネットの活用，財団法人 21 世紀 村づくり塾, pp. 57-58.

The purpose of this paper was to consider how to revitalize urban and rural interactions by using of Internet. We researched on web sites to get the trend of Internet informations originated in rural site, and we also conducted the case surveys from two points of views that were public views and business views. The cases were a rural planning group and a farm. The followings were observed: Internet would help to develop to organize a regional online community and interaction between urban and rural residents. Though there were serious issues remained; such as what types informations were needed by the urban residents were not thoroughly under stood by the rural residents.

Key Word: 1) Internet, 2) WEB Site, 3) Online Community, 4) Urban and Rural Interaction

(2001年11月 5 日 受理) 